\title{
Diatom-associated bacteria are required for aggregation of Thalassiosira weissflogii
}

\author{
Astrid Gärdes ${ }^{1}$, Morten H Iversen ${ }^{2,3}$, Hans-Peter Grossart ${ }^{4}$, Uta Passow ${ }^{3,5}$ \\ and Matthias S Ullrich ${ }^{1}$ \\ ${ }^{1}$ Jacobs University Bremen, School of Engineering and Science, Bremen, Germany; ${ }^{2}$ Department \\ of Geosciences, University of Bremen, Klagenfurterstrasse, Leobener Strasse, Bremen, Germany; \\ ${ }^{3}$ Alfred Wegener Institute for Polar and Marine Research, Bremerhaven, Germany; ${ }^{4}$ Institute of Freshwater \\ Ecology and Inland Fisheries, Alte Fischerhütte 2, Neuglobsow, Germany and ${ }^{5}$ Marine Science Institute, \\ University of California Santa Barbara, CA, USA
}

\begin{abstract}
Aggregation of algae, mainly diatoms, is an important process in marine systems leading to the settling of particulate organic carbon predominantly in the form of marine snow. Exudation products of phytoplankton form transparent exopolymer particles (TEP), which acts as the glue for particle aggregation. Heterotrophic bacteria interacting with phytoplankton may influence TEP formation and phytoplankton aggregation. This bacterial impact has not been explored in detail. We hypothesized that bacteria attaching to Thalassiosira weissflogii might interact in a yet-to-be determined manner, which could impact TEP formation and aggregate abundance. The role of individual $T$. weissflogii-attaching and free-living new bacterial isolates for TEP production and diatom aggregation was investigated in vitro. T. weissflogii did not aggregate in axenic culture, and striking differences in aggregation dynamics and TEP abundance were observed when diatom cultures were inoculated with either diatom-attaching or free-living bacteria. The data indicated that free-living bacteria might not influence aggregation whereas bacteria attaching to diatom cells may increase aggregate formation. Interestingly, photosynthetically inactivated $T$. weissflogii cells did not aggregate regardless of the presence of bacteria. Comparison of aggregate formation, TEP production, aggregate sinking velocity and solid hydrated density revealed remarkable differences. Both, photosynthetically active $T$. weissflogii and specific diatom-attaching bacteria were required for aggregation. It was concluded that interactions between heterotrophic bacteria and diatoms increased aggregate formation and particle sinking and thus may enhance the efficiency of the biological pump.

The ISME Journal (2011) 5, 436-445; doi:10.1038/ismej.2010.145; published online 9 September 2010

Subject Category: microbe-microbe and microbe-host interactions

Keywords: bacteria-phytoplankton interactions; marine aggregates; sinking flux; TEP; attachment assay
\end{abstract}

\section{Introduction}

Diatom blooms are frequently terminated by aggregation and subsequent sedimentation (Alldredge and Gotschalk, 1989; Jackson, 1990). The formation of large, fast sinking aggregates was proposed to be an integral part of the life cycle of many diatom species (Smetacek, 1985) but also contributes significantly to carbon flux thus being important for the global carbon cycle (Fowler and Knauer, 1986). Aggregation rates depend on the abundance and size of particles as well as on their environment, their relative sinking velocities and their stickiness (Kiørboe and Hansen, 1993; Jackson, 2001).

Correspondence: MS Ullrich, School of Engineering and Science, Jacobs University Bremen, Campusring 1, 28759 Bremen, Germany. E-mail: m.ullrich@jacobs-university.de

Received 3 May 2010; revised 5 July 2010; accepted 5 July 2010; published online 9 September 2010
The sticking efficiency of particles is thought to be a result of cellular exudation (Passow and Alldredge, 1995a), cell morphology (Kiørboe et al., 1990) and surface properties (Waite et al., 1995).

A major class of phytoplankton exudates are transparent exopolymer particles (TEP), which form the matrix of diatom aggregates (Alldredge et al., 1993) and promote aggregation of particles (Jackson, 1995; Logan et al., 1995; Engel, 2000). TEP, which form abiotically from precursor material released by diatoms (Passow, 2002b), accumulate during bloom development (Kiørboe et al., 1994; Jackson, 2005).

Release of exudates by diatoms is species-specific and depends on environmental conditions (Myklestad, 1995; Kahl et al., 2008). In laboratory experiments, three different types of aggregation behavior were distinguishable: (i) non-aggregating species that produce very little TEP (for example, Thalassiosira weissflogii), (ii) aggregating species that generate a cell coating of sticky TEP-like 
material but produce no free TEP (for example, Nitschia angularis) and (iii) species that generate copious amounts of TEP and form TEP-rich aggregates (for example, Chaetoceros sp.) (Logan et al., 1994; Crocker and Passow, 1995). In situ TEP concentration is coupled tightly with diatom concentrations suggesting that diatoms are the major producers of TEP (Passow, 2002a).

Bacteria may also produce TEP (Decho, 1990; Azam et al., 1994; Stoderegger and Herndl, 1999; Grossart et al., 2006a) and could play a crucial role in determining the sticking efficiency of algal cells using enzymes and extra-cellular products (Smith et al., 1995; Alderkamp et al., 2007). Grossart et al. (2006b) showed that heterotrophic bacteria influence the development and aggregation of marine diatoms such as $T$. rotula and Skeletonema costatum.

Marine bacteria and algae are thought to closely interact in the 'phycosphere', which is the micro-zone surrounding algal cells (Bell and Mitchell, 1972). Therein, bacteria may be free-living (Blackburn et al., 1998), may be attached to the algal surface (Kogure et al., 1981) or may occur as intracellular algal symbionts (Lewis et al., 2001). The attachment of bacteria to algal cells may represent a tight interaction (Cole, 1982; Grossart et al., 2005).

The aim of the present study was to analyze diatom-bacteria interactions, which induce TEP and aggregate formation in vitro. The individual impact of attaching versus free-living bacteria as well as the metabolic state of diatom cells on various characteristics of aggregates were studied in rolling tank experiments, which mimic continuous sinking of particles by rotating the liquid against gravity and thus allow the analysis of the formation of aggregates (Shanks and Edmondson, 1989; Ploug and Passow, 2007). It was hypothesized that formation rates, size-dependent densities and settling velocities of diatom aggregates differ in dependence of the physiological state of $T$. weissflogii and are influenced by presence of specific bacterial strains.

\section{Materials and methods}

Bacterial isolates

Five bacterial strains designated H14, Ex5, HP15, HP10 and HP2 were pre-selected from a total of 85 marine bacterial isolates (Supplementary Tables 1,2 and 3). Selection was based on results of the T. weissflogii attachment assay described below. Strains HP15, HP10 and HP2 were isolates from marine particulate samples collected in June and October 2000 from surface waters of the German Wadden Sea $\left(53^{\circ} 43^{\prime} 20^{\prime \prime} \mathrm{N}, \quad 07^{\circ} 43^{\prime} 20^{\prime \prime} \mathrm{E}\right)$ using a $100-\mu \mathrm{m}$ pore size plankton net (Grossart et al., 2004). Bacterial strains $\mathrm{H} 14$ and Ex5 were isolated from the sponge, Halichondria panacea, collected near the island of Helgoland, German Bight, in October 1997 and January 1999, respectively
(Wichels et al., 2006). Based on results of the T. weissflogii attachment assay, strains H14, Ex5, HP15 and HP10 were diatom-attaching whereas strain HP2 served as a free-living, non-attaching control strain.

Bacterial isolates were grown on marine broth agar plates (ZoBell, 1941) at the growth-optimizing temperature of $28{ }^{\circ} \mathrm{C}$. Bacterial cells were washed twice with and resuspended in sterile $\mathrm{f} / 2$ medium prepared with $>6$ months-old filtrated seawater (Guillard, 1975) to minimize carry-over of nutrients or bacterial growth-derived matter into diatom cultures (Grossart, 1999).

Axenic diatom cultures

Axenic cultures of T. weissflogii (CCMP 1336) were obtained from the Provasoli-Guillard National Center for Culture of Marine Phytoplankton (Maine, USA). Diatom cultures were grown in several replicates at $18^{\circ} \mathrm{C}$ in $\mathrm{f} / 2$ medium prepared as described above in 150-ml cell culture flask using a 12 -h light period at $115 \mu \mathrm{mol}$ photons $\mathrm{m}^{-2} \mathrm{~s}^{-1}$. After 9 days of growth, diatoms were transferred to fresh $\mathrm{f} / 2$ medium. Cultures were checked regularly for bacterial contamination by microscopic observations and agar plating.

\section{T. weissflogii attachment assay}

The attachment assay was conducted to select four bacterial isolates, which attached to T. weissflogii, and one bacterial isolate that remained nonattached. A total of 85 marine bacterial isolates (Supplementary Tables 1, 2 and 3) were tested for attachment. Three pools of bacterial isolates were generated according to the growth rates of the individual strains, which were determined by spectrometric analysis of the optical density $(\mathrm{OD}=600)$. Cells of each pool $(27-30$ bacterial isolates per pool) were collected, washed and incubated with $200 \mathrm{ml}$ cultures of axenic T. weissflogii for $24 \mathrm{~h}$. Control treatments without diatom cells were conducted in parallel (bacteria only). Subsequently, cultures were carefully passed through a $10-\mu \mathrm{m}$ plankton sieve by gravity flow to separate free-living bacterial cells from those attached to diatoms. Numbers of attached and freeliving bacteria were determined by dilution plating on marine broth agar and counts of colony forming units $\left(\mathrm{CFU} \mathrm{ml} \mathrm{m}^{-1}\right.$ ), which allowed determination of viable bacterial cells in both, the $>10 \mu \mathrm{m}$ fraction (attached bacteria) and the fraction of free-living bacteria. In all 14 attaching and 2 non-attaching colonies from the $>10 \mu \mathrm{m}$ fraction and the flowthrough fraction, respectively, were picked after 3 days of incubation at $22^{\circ} \mathrm{C}$ and identified by $16 \mathrm{~S}$ rRNA gene amplification and sequencing as follows: Universal 16S rRNA primers, GM3F and GM4R, specific for the domain Eubacteria (Muyzer and Ramsing, 1995) were used to amplify $16 \mathrm{~S}$ rRNA PCR fragments $\left(5 \mathrm{fmol} \mu \mathrm{l}^{-1}\right)$ for nucleotide sequencing 
using BIG dye terminator Sequencing kit (Applied Biosystems Inc., Norwalk, CT, USA).

Scanning electron microscopy of the $>10 \mu \mathrm{m}$ fraction was used to visualize and verify bacterial attachment to diatom cells following the procedure described by Martin-Cereceda et al. (2007).

\section{Rolling tank experiments}

A volume of $40 \mathrm{l}$ of diatom pre-cultures was grown in two 20-l cylinder flasks for 9 days at $18^{\circ} \mathrm{C}$ using a 12-h light period at $115 \mu \mathrm{mol}$ photons $\mathrm{m}^{-2} \mathrm{~s}^{-1}$ until they reached the late logarithmic growth phase. Sterile air with a $\mathrm{CO}_{2}$ partial pressure of $15 \mathrm{~Pa}$ was continuously pumped through the cultures to avoid inorganic carbon depletion. T. weissflogii cell abundance was daily monitored by counting cells in a Sedgwick-Rafter Cell S50 (SPI Supplies, West Chester, PA, USA) using an inverted Axiovert 200 microscope (Zeiss, Jena, Germany). The photosynthetic activity of diatoms was assessed using a pulse-amplitude-modulated (PAM) fluorometer as described below.

Different combinations of T. weissflogii cells, bacterial cells or glass beads were incubated in 1.15-l plexi glass cylinders with diameters of $14 \mathrm{~cm}$ and depths of $7.47 \mathrm{~cm}$. Five treatments were set up in duplicate (10 roller tanks) with photosynthetically active T. weissflogii plus either HP15, HP10, Ex5, H14 or the free-living control strain HP2. A second series of five rolling-tank treatments consisted of photosynthetically inactive $T$. weissflogii and the same five bacterial strains as above. Additionally, the following controls were run in duplicates: (1) axenic T. weissflogii cultures; (2) each of the five individual bacterial strains without diatoms; and (3) each of the five bacterial strains with glass beads (0.25-0.5 mm bead diameter) (Roth, Karlsruhe, Germany). Individual co-incubations were started by addition of $1 \mathrm{ml}$ of washed cells, harvested at an $\mathrm{OD}_{[600]}$ of 0.5 of a given bacterial strain to $1 \mathrm{l}$ of the axenic diatom culture, which was then diluted with $600 \mathrm{ml}$ of fresh $\mathrm{f} / 2$ medium. In the absence of diatoms, sterile $\mathrm{f} / 2$ media was added instead of cell suspensions. Initial diatom concentrations were $\sim 3000$ cells $\mathrm{ml}^{-1}$ and initial bacterial concentrations were $3 \times 10^{4} \mathrm{cells} \mathrm{ml}^{-1}$. Glass beads were added at a final concentration of $\sim 3000$ beads $\mathrm{ml}^{-1}$.

All 27 rolling tanks were rotated on a rolling table at three rotations per minute at $18{ }^{\circ} \mathrm{C}$ for 7 days. To avoid massive diatom replication, experiments were conducted in darkness, except for a $2-3 \mathrm{~h}$ light period per day, during which aggregates were counted or samples taken. Kinetics of dark-arrested T. weissflogii showed that these cells were not able to divide and withstood darkness for more than 2 weeks (Vaulot et al., 1986). Bacteria and TEP concentrations were determined after 24, 96 and $168 \mathrm{~h}$ of incubation. Samples of $5 \mathrm{ml}$ of aggregate-free water from rolling tanks were collected at each sampling time. From these, $200 \mu \mathrm{l}$ were used for the determination of bacterial cell numbers and $4 \mathrm{ml}$ were used for TEP measurements. Samples were collected in duplicates under sterile conditions using syringes and were immediately processed. Furthermore, aggregate abundance and sizedistribution in each roller tank was estimated after 24, 48, 96 and $168 \mathrm{~h}$ of incubation.

\section{Inactivation of $\mathrm{T}$. weissflogii}

Diatom cell suspensions were transferred to sterile 1-1 bottles, placed in a microwave set to $180 \mathrm{~W}$ for $90 \mathrm{~s}$, and subsequently incubated for $1 \mathrm{~h}$ at $18^{\circ} \mathrm{C}$ to inactivate cells (Judy et al., 1989). Cells were observed microscopically and photosynthetic activities were determined to ensure inactivation without physical destruction or cell lysis. Before and directly following the microwave treatment and again post incubation, photosynthetic activities were measured using a PAM fluorometer as described below.

\section{Determination of photosynthetic activity}

Photosynthetic activities of T. weissflogii cells were measured by the 'saturation pulse method' using a PAM fluorometer according to Schreiber (1986). Aliquots of cell suspensions were removed, placed into the PAM fluorometer, and dark-adapted for 15 min before measuring the photosynthetic activity according to established protocols (Genty et al., 1989). The quantum yield of charge separation in PSII, $\varphi p$, was determined according to equation (1)

$$
\varphi \mathrm{p}=(\mathrm{Fm}-\mathrm{F} 0) / \mathrm{Fm}
$$

where $\mathrm{Fm}$ is the maximum fluorescence and F0 represent the minimal fluorescence. Comparison of $\varphi p$ values verified the inactivation of microwaved $T$. weissflogii cells according to Kolber and Falkowski (1993).

\section{Determination of bacterial cell numbers}

In all, $200 \mu \mathrm{l}$ of the samples, collected from aggregate-free water in rolling tanks, were diluted 1:2 and $1: 10$ in sterile $\mathrm{f} / 2$ medium, fixed with $0.2-\mu \mathrm{m}$ pore size pre-filtered, borate-buffered $2 \%$ formalin and stained with $4^{\prime}$,6-diamino-2-phenylindole (DAPI; $1 \mu \mathrm{g} \mathrm{ml}^{-1}$ ) for $2 \mathrm{~min}$. Stained samples were filtered onto $0.2-\mu \mathrm{m}$ pore-sized polycarbonate Nucleopore filters (Whatman, Maidstone, England) in replicates and stored at $-20^{\circ} \mathrm{C}$. Bacterial cell numbers were counted for both replicates with ten random grid sectors per filter using an epifluorescence Axioplan microscope (Zeiss) at $\times 1000$ magnification according to an established method (Porter and Feig, 1980). Samples were counted within 2 weeks after sampling.

\section{TEP measurements}

Free TEP concentrations were quantified using the dye-binding assay for spectrophotometric 
measurements (Passow and Alldredge, 1995b). Four $\mathrm{ml}$ samples were taken from aggregate-free water of rolling tanks. Before staining, $1 \mathrm{ml}$ aliquots were filtered in triplicates at low constant vacuum (max $150 \mathrm{~mm}$ of $\mathrm{Hg}$ ) onto $0.4-\mu \mathrm{m}$ pore sized Nucleopore polycarbonate filters. TEP were stained on the filter for $30 \mathrm{~s}$ with $500 \mu \mathrm{l}$ precalibrated $0.02 \%$ aqueous solution of Alcian blue (8GX) in $0.06 \%$ acetic acid ( $\mathrm{pH}$ 2.5). Filters were then rinsed once with distilled water to remove excess dye, the dye was dissolved in sulfuric acid and measured in a spectrophotometer at $787 \mathrm{~nm}$.

\section{Determination of aggregate sinking velocity}

Size-specific sinking velocity of aggregates was determined in a vertical flow system (Ploug and Jørgensen, 1999). Individual aggregates were gently transferred from the rolling tanks to an open flowthrough chamber using a wide-tipped pipette. The open flow-through chamber consisted of a $10-\mathrm{cm}$ high Plexi glass tube $(5 \mathrm{~cm}$ diameter $)$ with a net located in the middle. The net created a relatively uniform flow field across the upper chamber when a flow was applied from below (Ploug and Jørgensen, 1999). The sinking velocity of an aggregate was calculated by dividing the flow rate by the crosssectional area of the flow chamber. Triplicate measurements of sinking velocity were made for each aggregate. The lengths of all three aggregate axis ( $\mathrm{x}, \mathrm{y}$ and $\mathrm{z}$ direction) were measured in the flow system using a horizontal dissection microscope with a calibrated ocular. The aggregate volumes were calculated by assuming ellipsoid aggregate shapes. For comparison with other aggregates, the equivalent spherical diameter was calculated (diameter of a sphere with equivalent volume).

\section{Measurement of the solid hydrated density of aggregates}

The solid hydrated density $\left(\rho_{s}, \mathrm{~g} \mathrm{~cm}^{-3}\right)$ of the particles inside the aggregates was determined in a density gradient using a modified version of previously reported methods (Schwinghamer, 1991; Feinberg and Dam, 1998). Seven dilutions were made using Ludox TM colloidal silica (SigmaAldrich, Munich, Germany), sucrose and distilled water ranging in density from 1.05 to $1.43 \mathrm{~g} \mathrm{~cm}^{-3}$. Dilutions were buffered to $\mathrm{pH} 8.1$ with $0.0125 \mathrm{M}$ Tris plus $0.0125 \mathrm{M}$ Tris-HCl (final concentration). Thus, the produced gradient was iso-osmotic with seawater of a salinity of $\sim 32 \%$ (Weast, 1968). Two $\mathrm{ml}$ of each dilution were gently transferred to a 20-ml centrifuge tube, beginning with the densest and finishing with the least dense dilution. The density gradients were stored at $5{ }^{\circ} \mathrm{C}$ overnight and allowed to warm to room temperature before use. One ml of sterile seawater (32\%) was gently applied on top of the density gradient. Single aggregates were transferred to individual centrifugation tubes using a wide-tipped pipette letting the aggregates settle into the seawater layer without breaking. Next, samples were centrifuged at 3000 r.p.m. for $30 \mathrm{~min}$ and $1 \mathrm{ml}$ from the density layers containing the aggregate were removed from the tube using a peristaltic pump and weighed using a Mettler Toledo fine-balance (Mettler Toledo, Giessen, Germany). Average densities were calculated. In case aggregates broke during settling, several 1-ml samples of the density gradient were screened for particles using a dissection microscope and subjected to weighing.

\section{Statistical analyses}

A simple one-way analysis of variance was carried out to assess differences in TEP, bacterial cell numbers and aggregate abundance between axenic and bacteria-containing treatments. The same type of analysis was applied for cell numbers of the four bacterial strains attaching to diatoms (HP15, H14, HP10 and Ex5) and the free-living strain (HP2) when incubated in rolling tanks.

\section{Results}

Attachment assay

When pools of bacterial strains were incubated with T. weissflogii cell suspensions, variable numbers of bacterial cells were found to be attached to the diatoms but all three pools showed a similar

Table 1 T. weissflogii attachment assay

\begin{tabular}{|c|c|c|c|c|c|c|}
\hline \multirow[t]{3}{*}{ Bacterial abundance $\left(\times 10^{6}\right) \mathrm{CFU} \mathrm{ml^{-1 }}$} & \multirow{2}{*}{\multicolumn{2}{|c|}{$\begin{array}{c}\text { Bacterial pool } 1 \\
\text { T. weissflogii }\end{array}$}} & \multirow{2}{*}{\multicolumn{2}{|c|}{$\begin{array}{c}\text { Bacterial pool } 2 \\
\text { T. weissflogii }\end{array}$}} & \multirow{2}{*}{\multicolumn{2}{|c|}{$\begin{array}{c}\text { Bacterial pool } 3 \\
\text { T. weissflogii }\end{array}$}} \\
\hline & & & & & & \\
\hline & With & Without & With & Without & With & Without \\
\hline$t=0$, total & 1.04 & 1.24 & 1.19 & 1.12 & 1.80 & 2.02 \\
\hline$t=1 \mathrm{~d}$, total & 0.88 & 0.58 & 0.33 & 0.78 & 2.40 & 1.80 \\
\hline$t=1 \mathrm{~d}$, attached bacteria & 0.19 & 0.0024 & 0.24 & 0.0018 & 0.88 & 0.0075 \\
\hline$t=1 \mathrm{~d}$, free-living bacteria & 0.40 & 0.38 & 0.19 & 0.60 & 1.30 & 1.50 \\
\hline
\end{tabular}

Three bacterial pools were separately incubated with T. weissflogii cell cultures. Bacterial abundances in CFU ml ${ }^{-1}$ for attached bacteria and free-living bacteria were determined. Bacteria incubated without diatoms served as control. 
tendency (Table 1). Numbers of diatom-attached bacteria were highest in co-incubations with pool three with $8.8 \times 10^{5} \mathrm{CFU} \mathrm{m}^{-1}$ (attached fraction) thereby accounting for almost half of the initially inoculated cell number $\left(1.8 \times 10^{6} \mathrm{CFU} \mathrm{ml}^{-1}\right)$. Data for the respective control treatment showed that a very small number of bacterial cells $(7.5 \times$ $10^{3} \mathrm{CFU} \mathrm{ml}^{-1}$ ) were retained on filters (attached fraction) when no diatom cells were present. This control was confirmed microscopically and demonstrated that there was specific attachment to T. weissflogii cells and that there was very limited unspecific binding of bacterial cells to the filters or aggregation of bacterial cells.

Bacterial cells from the attached fractions of all three pools were subjected to colony typing and $16 \mathrm{~S}$ rRNA sequencing. Data were compared with those of the initial bacterial isolates (Supplementary Tables 1, 2, and 3). Isolates HP15, HP10, Ex5 and H14 were found to be best represented in the attached fractions. Isolate HP2 was identified as a typical free-living bacterial strain isolated from the flow-through.

Diatom-attaching bacterial strains belonged to different phylogenetic groups: Strains HP15 was originally isolated from marine particles and assigned to the Gammaproteobacteria genus Marinobacter. Strain HP10 was also isolated from marine particles and represented a Gram-positive species of the Firmicutes. The $16 \mathrm{~S}$ rRNA of strain Ex5 had 98\% similarities to Psychroserpens burtonensis belonging to Flavobacteria. Strain H14 was another member of the Gammaproteobacteria. The freeliving strain HP2 was found to be a member of the Flexibacter genus belonging to Bacteroidetes.

In order to verify the diatom-attaching phenotypes, all five strains were again individually subjected to the attachment assay. As expected, strains HP15, HP10, Ex5 and H14 attached to diatoms whereas strain HP2 did not (Data not shown). Moreover, samples from the co-incubation of strain HP15 with T. weissflogii were subjected to scanning electron microscopy (Figure 1), which revealed a clear physical association of both organisms and no formation of bacterial aggregates.

\section{Aggregate formation in rolling tanks}

Aggregate formation of photosynthetically active diatoms in rolling tanks differed significantly between axenic and bacteria-containing treatments $(P \leqslant 0.03)$, and between treatments containing the attaching bacterial strains HP15, HP10, Ex5 and H14 or the free-living control strain HP2 $(P<0.05)$ (Figure 2). No aggregates formed in rolling tanks containing axenic, photosynthetically active T. weissflogii, cultures throughout the incubation period suggesting that activity of the diatom-attaching strains was vital for aggregate formation of this diatom. When T. weissflogii cells were co-incubated with any of the four attaching bacterial strains

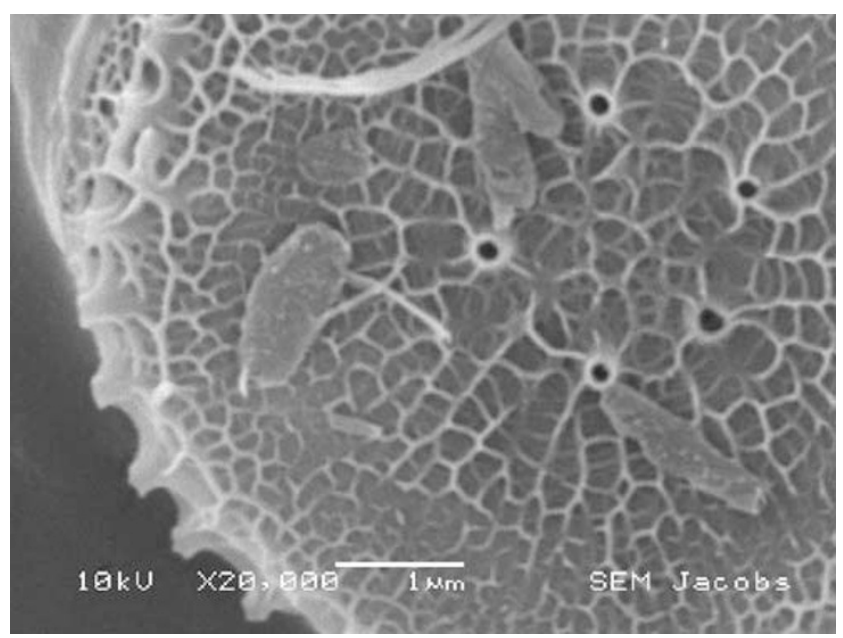

Figure 1 Scanning electron microscopy of a T. weissflogii cell with four cells of the attaching bacterial strain, HP15. Bacteria attached to T. weissflogii within $24 \mathrm{~h}$ of incubation. Scale bar $1 \mu \mathrm{m}$

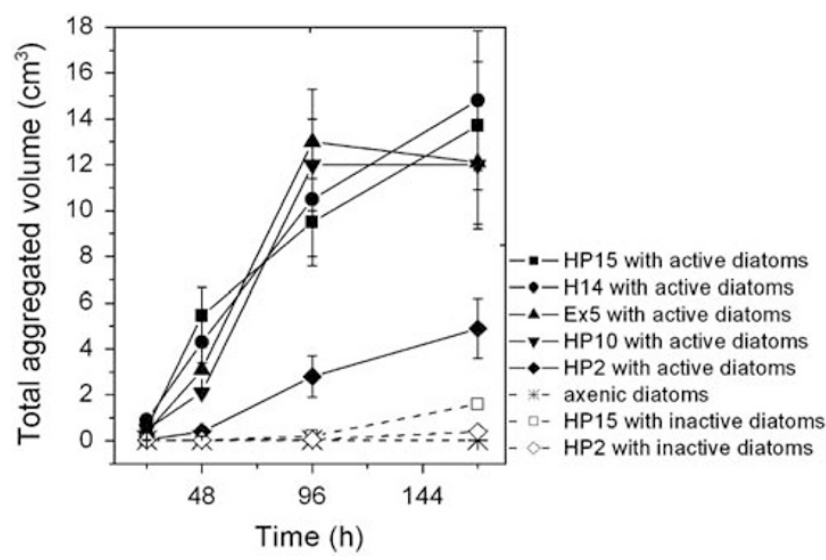

Figure 2 Total aggregated volumes $\left(\mathrm{cm}^{3}\right)$ per rolling tank during $168 \mathrm{~h}$ of incubation. Photosynthetic active T. weissflogii cultures were separately incubated with the attaching bacteria strains, HP15, H14, HP10 and Ex5, or the non-attaching bacterial strain, HP2, in duplicates. Axenic T. weissflogii culture served as control. Photosynthetic inactive T. weissflogii cultures incubated with attaching strain, HP15, and non-attaching strain, HP2, as controls. Error bars represent biological replicates (duplicates), s.e.

(HP15, HP10, Ex5 and H14), the total aggregated volumes increased to an average of $\sim 14 \mathrm{~cm}^{3} \mathrm{l}^{-1}$ after $168 \mathrm{~h}$ of incubation. There was no significant difference in final aggregate abundance (30 \pm 7.5 aggregates per tank with aggregate diameters of $3-5 \mathrm{~mm}$ ) or total aggregated volume between incubations of the attaching-bacterial strains $(P<0.262)$. These results indicated that any of these bacterial species were capable of inducing diatom aggregation. However, diatom aggregation dynamics differed for individual bacterial strains. Total aggregated volume increased steadily in rolling tanks containing bacterial strains $\mathrm{H} 14$ and HP15. In contrast total aggregated volume in treatments with strains HP10 and Ex5 were lower at $48 \mathrm{~h}$ and peaked at $96 \mathrm{~h}$. Interestingly, the total aggregated volume in 
the treatment with the non-attaching bacterial strain, HP2, was roughly threefold lower after $168 \mathrm{~h}\left(4 \mathrm{~cm}^{3} \mathrm{l}^{-1}\right)$, and no aggregation occurred within the first $48 \mathrm{~h}$ (Figure 2). When incubated with glass beads, none of the five bacterial isolates led to aggregate formation (Data not shown).

The impact of $T$. weissflogii metabolism on aggregate formation was investigated by co-incubations of bacteria with photosynthetically inactive diatom cells (Figure 2). Analysis of the photosynthetic activities using PAM fluorometer determined active diatoms with $\varphi p=0.57$ and inactive diatoms with $\varphi p=0.21$, which is in line with previous findings (Kolber and Falkowski, 1993). Microscopic observations confirmed that both, photosynthetically active and inactive diatoms, were colonized by T. weissflogii-attaching strains (Data not shown). However, photosynthetically inactive T. weissflogii cultures showed 9- and 12-fold lower aggregation rates when incubated with strains HP15 and HP2, respectively, as compared with photosynthetically active diatom cultures. Similar aggregate patterns were observed for photosynthetically inactive T. weissflogii cultures incubated with the bacterial isolates HP10, Ex5 and H14 (Data not shown). These results suggested that both, attaching bacteria and photosynthetically active T. weissflogii cells, were required for aggregate formation.

\section{Aggregate characteristics}

Sinking velocities and solid hydrated densities were determined for aggregates formed in rolling tank experiments from all five treatments with photosynthetically active diatoms and all five treatments with photosynthetically inactive diatoms as well as those formed with inactive axenic diatoms. Data were determined in duplicates.

Sinking velocities of aggregates generally increased with increasing aggregate sizes reaching $50 \mathrm{~m} \mathrm{~d}^{-1}$ for aggregates with an equivalent spherical diameter of $\sim 1 \mathrm{~mm}$ and $300 \mathrm{~m} \mathrm{~d}^{-1}$ for aggregates with an equivalent spherical diameter of $\sim 4 \mathrm{~mm}$ (Figure 3a). Sinking velocity of aggregates formed in the presence of bacterial cells did not differ from those formed without bacteria. Using a power law when plotting sinking velocities versus the equivalent spherical diameters, the correlation coefficient ( $R$-squared value) was high $\left(R^{2}=0.81\right)$ indicating a strong positive linear relationship (Figure $3 \mathrm{~b}$ ).

Likewise, no differences were observed for the solid hydrated densities of aggregates between T. weissflogii cultures incubated with or without bacterial strains and ranged between 1.15 and $1.21 \mathrm{~g} \mathrm{~cm}^{-3}$ with an average value of $1.17 \pm 0.02 \mathrm{~g} \mathrm{~cm}^{-3}$. These data indicated that the measured aggregate characteristics were not influenced by the presence of bacteria.

Dynamics of bacterial cell numbers and TEP formation Bacterial cell numbers and TEP concentrations in aggregate-free rolling tank samples were quantified for treatments with photosynthetically active and inactive T. weissflogii cells (Figure 4). When photosynthetically active $T$. weissflogii cells were incubated with the attaching strains, HP15, HP10, Ex5 and $\mathrm{H} 14$, bacterial cell numbers increased rapidly within the first $96 \mathrm{~h}$ and reached values ranging from $2 \times 10^{5}$ to $1 \times 10^{6}$ cells ml $\mathrm{m}^{-1}$ (average $=8.9 \times$ $10^{5} \pm 1.0 \times 10^{5} \mathrm{cells} \mathrm{ml}^{-1}$ ) independent of the individual strains (Figures $4 a-d$ ). These results suggested that bacterial cells potentially benefited from photosynthetically products released by $T$. weissflogii. After 96 until $168 \mathrm{~h}$, bacterial cell numbers remained relatively stable. However, intermediate and maximum bacterial cell numbers of the non-attaching isolate, HP2, were significantly lower (on average $5.1 \times 10^{5}$ cells ml ${ }^{-1} \pm 0.6 \times 10^{5}$ cells ml $^{-1}$ ) as compared with those of attaching bacterial isolates (Figure 4e). This indicated that the non-attaching bacterial isolate could possibly not
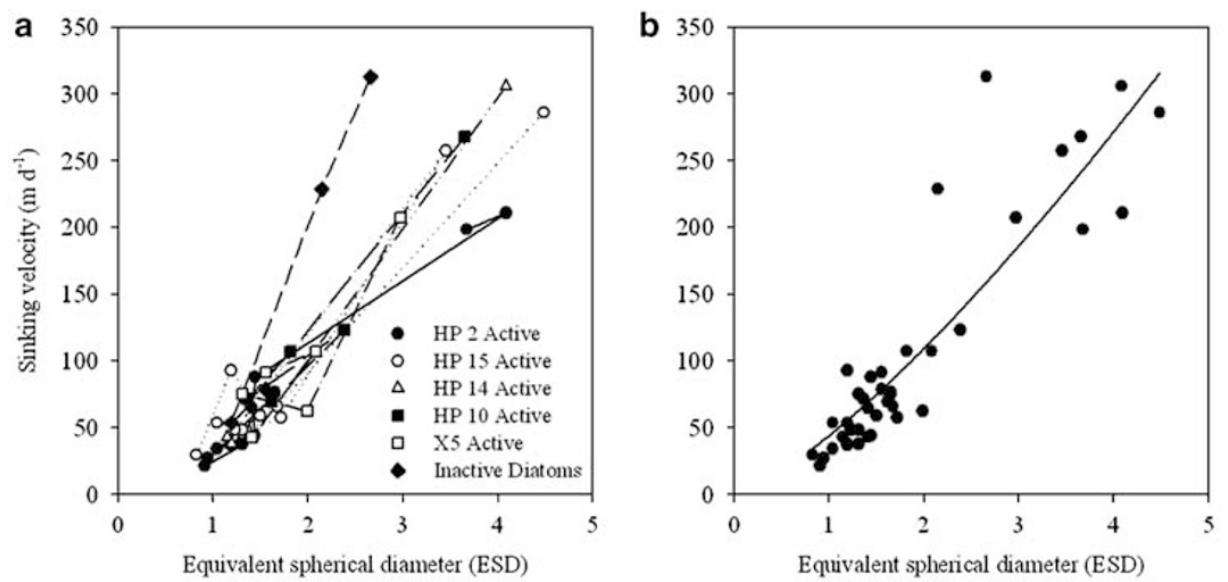

Figure 3 Sinking velocities of aggregates collected after $168 \mathrm{~h}$ of incubation as a function of aggregate diameter (ESD in mm). (a) Aggregates formed by T. weissflogii and the attaching bacterial strains, HP15, H14, HP10 and Ex5, as well as the non-attaching bacterial strain, HP2. (b) Pooled sinking velocities for all aggregate types measured as a function of aggregate diameter. A power equation was fitted to the measurements: sinking velocities $=44.11 \mathrm{ESD}^{1.31} ; R^{2}=0.81 ; P<0.0001$. 

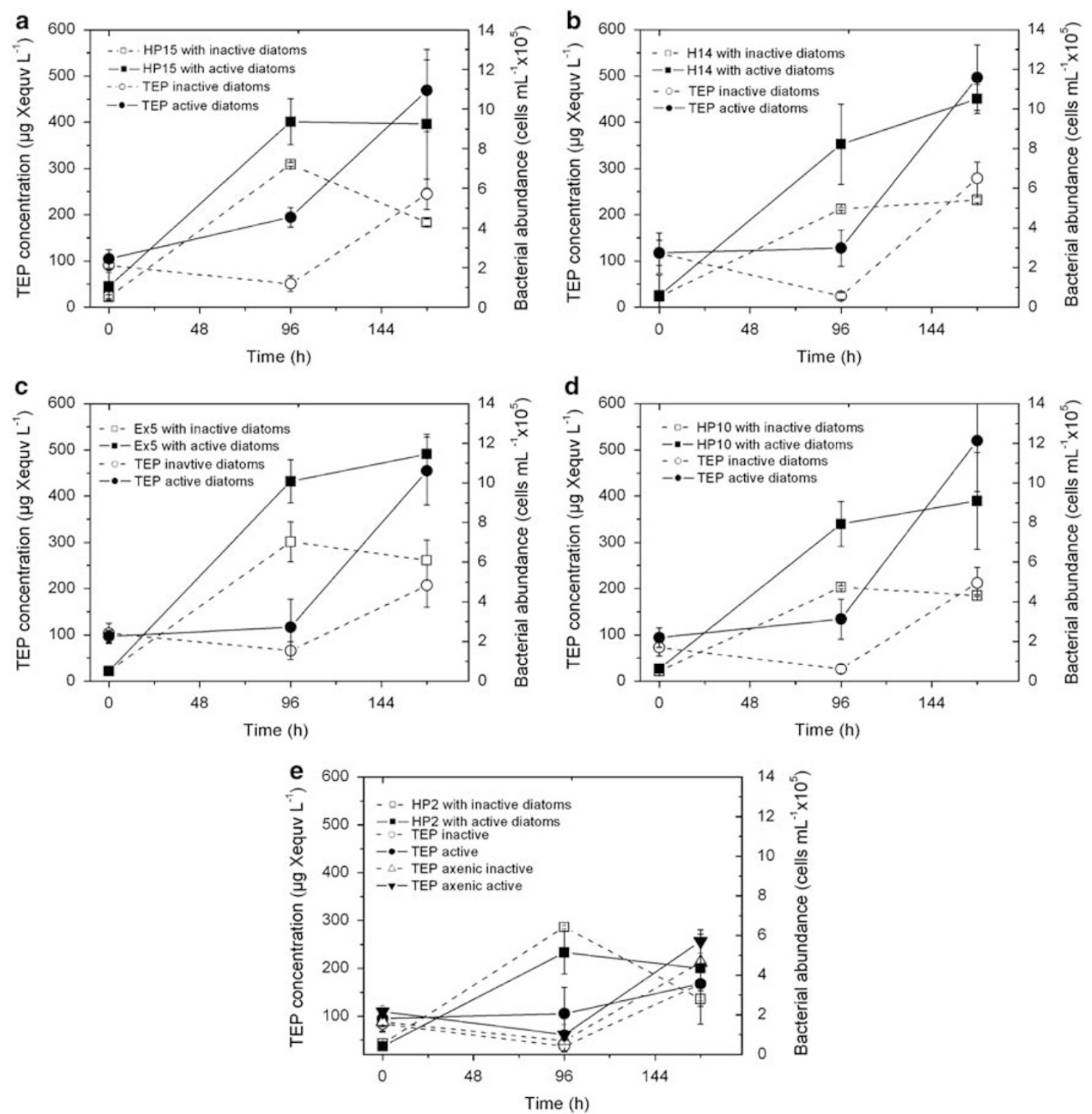

Figure 4 Abundance of TEP and bacterial cell numbers versus time during rolling tank experiments. (a) Treatment with HP15 (b) treatment with $\mathrm{H} 14$, (c) treatment with Ex5, (d) treatment with HP10, (e) treatment with HP2 and axenic T. weissflogii cultures as controls. Error bars represent technical replicates (triplicates), s.d.

use diatom-derived substrates as efficiently as the attaching bacterial strains.

TEP concentrations in treatments with photosynthetically active $T$. weissflogii and the attaching bacterial strains, HP15, HP10, H14 and Ex5, increased moderately within the first $96 \mathrm{~h}$ but more rapidly thereafter (Figures $4 \mathrm{a}-\mathrm{d}$ ). At $168 \mathrm{~h}$ of incubation, maximum values with an average of $431 \pm 27 \mu$ Xequv $^{-1}$ were reached. TEP concentrations of these treatments were higher than those of axenic T. weissflogii cultures. Interestingly, TEP formation was negligible when T. weissflogii cells were co-incubated with the non-attaching bacterial strain, HP2 (Figure 4e) suggesting that this strain might not foster TEP formation by the diatom cells.

During the first $96 \mathrm{~h}$ bacterial abundances in treatments with photosynthetically inactive
T. weissflogii (Figures 4a-e) showed similar tendencies as those observed for photosynthetically intact diatoms. However, bacterial cell numbers decreased thereafter reaching maximum values of $\sim 5 \times 10^{5} \mathrm{cells} \mathrm{ml}^{-1}$ (average $4.6 \times 10^{5} \pm 1.2 \times$ $10^{5} \mathrm{cells} \mathrm{ml}^{-1}$ ) (Figures 4a-d). This decrease was even more pronounced for the incubation with the non-attaching strain, HP2 (Figure 4e). These results indicated that photosynthetically active diatom cells are required for optimal bacterial growth and that inactive T. weissflogii provide only a basic nutritional resource for bacteria. In controls with bacterial cells only or with bacteria and glass beads, the bacterial abundance decreased gradually from $4.7 \times 10^{4} \pm 1.8 \times 10^{3} \mathrm{cells} \mathrm{ml}^{-1}$ at the beginning of incubation to $2.3 \times 10^{4} \pm 7.8 \times 10^{3}$ cells ml $\mathrm{m}^{-1}$ at $168 \mathrm{~h}$ (data not shown). 


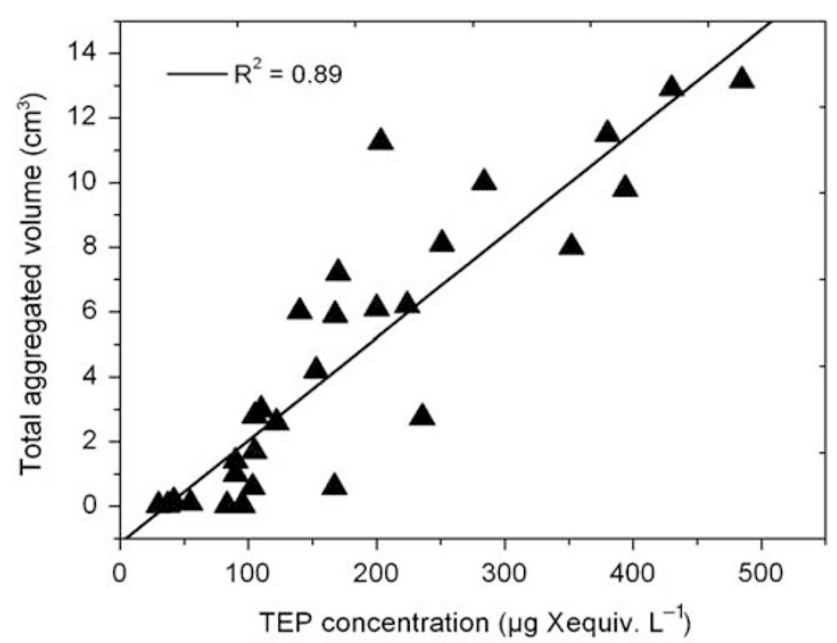

Figure 5 Correlation of total aggregated volumes and TEP concentrations in rolling tank experiments. Linear regression was fitted to measurements $N=30 ; R^{2}=0.89 ; P<0.0001$.

When photosynthetically inactive T. weissflogii cultures were incubated with bacterial isolates, TEP concentrations decreased during the first $96 \mathrm{~h}$ but increased to an average of $\sim 222 \pm 42 \mu \mathrm{g} \mathrm{Xequv}^{-1}$ at $168 \mathrm{~h}$ (Figures 4a-d). Similar TEP concentrations were found for the axenic diatom controls $(250 \mu \mathrm{g}$ Xeuqv $^{-1}$ ) after $168 \mathrm{~h}$ of incubation (Figure $4 \mathrm{e}$ ).

TEP concentrations showed a strong positive linear relationship with the total aggregate volumes giving a linear regression of $R^{2}=0.89$ (Figure 5). With increasing total aggregate volumes TEP concentrations increased.

\section{Discussion}

For the first time, this study demonstrated that under defined in vitro conditions specific bacterial strains attaching to T. weissflogii as well as photosynthetically active $T$. weissflogii cells are both required for TEP production and aggregate formation. It could be clearly demonstrated that aggregate abundance correlated with TEP concentration. This observed relationship had frequently been postulated but was not shown experimentally before (Kiørboe and Hansen, 1993; Passow and Alldredge, 1995a; Azetsu-Scott and Passow, 2004).

In an earlier study $T$. weissflogii was shown to form little TEP and to not form aggregates (Crocker and Passow, 1995). However, later it was observed that this diatom species generated copious amounts of TEP (Passow, 2002a). It is possible that the diatom cultures used in both studies differed in terms of bacterial contaminations, which according to results of the current study, might induce TEP formation and aggregation.

In contrast to previous studies (Grossart et al., 2006a; Grossart and Simon, 2007), in the current study, attaching bacterial isolates and one non-attaching bacterial isolate were comparatively analyzed with respect to their interactions with photosynthetically active and inactive diatom cells. It was demonstrated that not any type of bacterial isolate was able to elicit aggregation of $T$. weissflogii and TEP formation but that only attaching species did so. Despite the short time of light exposure used in this study, a photosynthetically active status of T. weissflogii seemed to be required to produce large amounts of TEP precursor material. Noteworthy, diatom exudates such as surface-active sugars might be affected by the applied inactivation procedure. In turn, this would change the sticking efficiency of diatom cells as described by others (Waite et al., 1995; Staats et al., 2000; Tien et al., 2005) and thus might lower the probability of aggregate formation. Under natural conditions marine bacteria may benefit from diatom photosynthesis in the form of either (i) actively interacting with the algae thereby influencing TEP formation (and aggregation) or (ii) in a non-interacting, free-living manner by utilizing dissolved organic matter released during the hydrolysis of diatom exudates and TEP. Alternatively, bacteria may actively contribute to the TEP pool as suggested earlier (Stoderegger and Herndl, 1999; Passow, 2002a; Bhaskar et al., 2005).

The observed aggregate characteristics did not differ between treatments with different bacterial strains attaching to T. weissflogii. A general tendency for increasing sinking velocity with increasing aggregate sizes was found thus confirming previous in situ results for natural aggregates and from laboratory experiments (Ploug et al., 2008). The average values for solid hydrated densities obtained herein were comparable with previously estimated values for in situ diatom aggregates (Alldredge and Gotschalk, 1989). Results of the current study suggested a rather minor impact of bacteria on the estimated aggregate characteristics but showed their importance for T. weissflogii aggregation. Thus, this study provided experimental evidence supporting a contribution of bacterial activities to the biological pump (Fowler and Knauer, 1986).

A direct cellular interaction of diatoms with bacteria may be required for TEP formation and aggregation dynamics. This interaction might be as important for aggregation as are environmental conditions such as concentrations of nutrients, vitamins and trace metals (Grossart, 1999; Beauvais et al., 2006; Grossart and Simon, 2007). Aggregation could occur as a result of nutrient stress of T. weissflogii as suggested earlier (Grossart, 1999; Grossart and Simon, 2007). The observed differential effects of nonattaching and attaching bacteria on aggregate formation may be the consequence of nutrient competition between algae and attaching bacteria. Hence, this interaction might vary significantly in situ depending on changes in bacterial community composition, which may explain the high variability of diatom aggregation patterns observed in previous studies (Kiørboe and Hansen, 1993; Passow and Alldredge, 1995a; Azam and Malfatti, 2007). 
The current results offer an experimental basis for establishing an in vitro model system, in which bilateral cellular interactions can be studied indepth. This potentially will allow further studies on ecological consequences of bacteria-phytoplankton interactions not only in defined experimental set-ups but also in natural habitats.

\section{Acknowledgements}

We would like to thank Antje Wichels for support and providing bacterial isolates, Sven Kranz for assistance in determining the photosynthetic activity using PAM, Veit Wagner, Arne Hoppe and Yannic Ramaye support when using the scanning electron microscope. This work was financially supported by Jacobs University Bremen and Deutsche Forschungsgemeinschaft (GR1540-12/1).

\section{References}

Alderkamp AC, van Rijssel M, Bolhuis H. (2007). Characterization of marine bacteria and the activity of their enzyme systems involved in degradation of the algal storage glucan laminarin. Fems Microbiology Ecology 59: 108-117.

Alldredge AL, Gotschalk CC. (1989). Direct observations of the mass flocculation of diatom blooms: characteristics, settling velocities and formation of diatom aggregates. Deep Sea Research Part A. Oceanographic Research Papers 36: 159-171.

Alldredge AL, Passow U, Logan BE. (1993). The abundance and significance of a class of large, transparent organic particles in the ocean. Deep-Sea Research Part I-Oceanographic Research Papers 40: 1131-1140.

Azam F, Malfatti F. (2007). Microbial structuring of marine ecosystems. Nature Reviews Microbiology 5: 782-791 (Review. Erratum in: Nat Rev Microbiol. 2007 5(12):966).

Azam F, Smith DC, Steward GF, Hagstrom A. (1994). Bacteria-organic-matter coupling and its significance for oceanic carbon cycling. Microbial Ecology 28: 167-179.

Azetsu-Scott K, Passow U. (2004). Ascending marine particles: significance of transparent exopolymer particles (TEP) in the upper ocean. Limnology and Oceanography 49: 741-748.

Beauvais S, Pedrotti ML, Egge J, Iversen K, Marrase C. (2006). Effects of turbulence on TEP dynamics under contrasting nutrient conditions: implications for aggregation and sedimentation processes. Marine Ecology-Progress Series 323: 47-57.

Bell W, Mitchell R. (1972). Chemotactic and growth responses of marine bacteria to algal extracellular products. Biological Bulletin 143: 265.

Bhaskar PV, Grossart HP, Bhosle NB, Simon M. (2005). Production of macroaggregates from dissolved exopolymeric substances (EPS) of bacterial and diatom origin. Fems Microbiology Ecology 53: 255-264.

Blackburn N, Fenchel T, Mitchell J. (1998). Microscale nutrient patches in planktonic habitats shown by chemotactic bacteria. Science 282: 2254-2256.

Cole JJ. (1982). Interactions between bacteria and algae in aquatic ecosystems. Annual Review of Ecology and Systematics 13: 291-314.
Crocker KM, Passow U. (1995). Differential aggregation of diatoms. Marine Ecology-Progress Series 117: 249-257.

Decho AW. (1990). Microbial exopolymer secretions in ocean environments-their role(s) in food webs and marine processes. Oceanography and Marine Biology 28: 73-153

Engel A. (2000). The role of transparent exopolymer particles (TEP) in the increase in apparent particle stickiness (alpha) during the decline of a diatom bloom. Journal of Plankton Research 22: 485-497.

Feinberg LR, Dam HG. (1998). Effects of diet on dimensions, density and sinking rates of fecal pellets of the copepod Acartia tonsa. Marine Ecology Progress Series 175: 87-96.

Fowler SW, Knauer GA. (1986). Role of large particles in the transport of elements and organic compounds through the oceanic water column. Progress in Oceanography 16: 147-194.

Genty B, Briantais JM, Baker NR. (1989). The relationship between the quantum yield of photosynthetic electron-transport and quenching of chlorophyll fluorescence. Biochimica Et Biophysica Acta 990: 87-92.

Grossart HP. (1999). Interactions between marine bacteria and axenic diatoms (Cylindrotheca fusiformis, Nitzschia laevis, and Thalassiosira weissflogii) incubated under various conditions in the lab. Aquatic Microbial Ecology 19: 1-11.

Grossart HP, Czub G, Simon M. (2006a). Algae-bacteria interactions and their effects on aggregation and organic matter flux in the sea. Environmental Microbiology 8: 1074-1084.

Grossart HP, Kiorboe T, Tang KW, Allgaier M, Yam EM, Ploug H. (2006b). Interactions between marine snow and heterotrophic bacteria: aggregate formation and microbial dynamics. Aquatic Microbial Ecology 42: 19-26.

Grossart HP, Levold F, Allgaier M, Simon M, Brinkhoff T. (2005). Marine diatom species harbour distinct bacterial communities. Environmental Microbiology 7: 860-873.

Grossart HP, Schlingloff A, Bernhard M, Simon M, Brinkhoff T. (2004). Antagonistic activity of bacteria isolated from organic aggregates of the german wadden sea. Fems Microbiology Ecology 47: 387-396.

Grossart HP, Simon M. (2007). Interactions of planktonic algae and bacteria: effects on algal growth and organic matter dynamics. Aquatic Microbial Ecology 47: 163-176.

Guillard RRL. (1975). Culture of phytoplankton for feeding marine invertebrates. In: Smith WL, Chanley MH (eds). Culture of Marine Invertebrate Animals. Plenum Press: New York, USA, pp 108-132.

Jackson GA. (1990). A model of the formation of marine algal flocs by physical coagulation processes. Deep Sea Research Part A. Oceanographic Research Papers 37: 1197-1211.

Jackson GA. (1995). TEP and coagulation during a mesocosm experiment. Deep Sea Research Part II: Topical Studies in Oceanography 42: 215-222.

Jackson GA. (2001). Effect of coagulation on a model planktonic food web. Deep Sea Research Part I: Oceanographic Research Papers 48: 95-123.

Jackson GA. (2005). Coagulation theory and models of oceanic plankton aggregation. In: Droppo I, Leppard G, Liss S, Milligan T (eds). Flocculation in Natural and Engineered Environmental Systems. CRC Press. pp 271-292. 
Judy D, Clarice MY, Sara M, Colleen M. (1989). Rapid analytical technique for the assessment of cell metabolic activity in marine microalgae. Cytometry 10: 622-628.

Kahl LA, Vardi A, Schofield O. (2008). Effects of phytoplankton physiology on export flux. Marine Ecology-Progress Series 354: 3-19.

Kiørboe T, Andersen KP, Dam HG. (1990). Coagulation efficiency and aggregate formation in marine phytoplankton. Marine Biology 107: 235-245.

Kiørboe T, Hansen JLS. (1993). Phytoplankton aggregate formation: observations of patterns and mechanisms of cell sticking and the significance of exopolymeric material. J Plankton Res 15: 993-1018.

Kiørboe T, Lundsgaard C, Olesen M, Hansen JLS. (1994). Aggregation and sedimentation processes during a spring phytoplankton bloom-a field experiment to test coagulation theory. Journal of Marine Research 52: 297-323.

Kogure K, Simidu U, Taga N. (1981). Bacterial attachment to phytoplankton in sea-water. Journal of Experimental Marine Biology and Ecology 56: 197-204.

Kolber Z, Falkowski PG. (1993). Use of active fluorescence to estimate phytoplankton photosynthesis in-situ. Limnology and Oceanography 38: 1646-1665.

Lewis J, Kennaway G, Franca S, Alverca E. (2001). Bacterium-dinoflagellate interactions: investigative microscopy of Alexandrium spp. (Gonyaulacales, Dinophyceae). Phycologia 40: 280-285.

Logan BE, Grossart HP, Simon M. (1994). Direct observation of phytoplankton, Tep and aggregates on polycarbonate filters using brightfield microscopy. Journal of Plankton Research 16: 1811-1815.

Logan BE, Passow U, Alldredge AL, Grossart HP, Simon M. (1995). Rapid formation and sedimentation of large aggregates is predictable from coagulation rates (half-lives) of transparent exopolymer particles (Tep). Deep-Sea Research Part Ii-Topical Studies in Oceanography 42: 203-214.

Martin-Cereceda M, Williams R, Guinea A, Novarino G. (2007). An investigation of the fine structure, cell surface carbohydrates, and appeal of the diatom Extubocellulus sp as prey for small flagellates. Protoplasma 232: 69-78.

Muyzer G, Ramsing NB. (1995). Molecular methods to study the organization of microbial communities. Water Science and Technology 32: 1-9.

Myklestad SM. (1995). Release of extracellular products by phytoplankton with special emphasis on polysaccharides. Science of the Total Environment 165: $155-164$.

Passow U. (2002a). Production of transparent exopolymer particles (TEP) by phyto- and bacterioplankton. Marine Ecology-Progress Series 236: 1-12.

Passow U. (2002b). Transparent exopolymer particles (TEP) in aquatic environments. Progress in Oceanography 55: 287-333.

Passow U, Alldredge AL. (1995a). Aggregation of a diatom bloom in a mesocosm-the role of transparent exopolymer particles (Tep). Deep-Sea Research Part Ii-Topical Studies in Oceanography 42: 99-109.

Passow U, Alldredge AL. (1995b). A dye-binding assay for the spectrophotometric measurement of transparent exopolymer particles (TEP). Limnology and Oceanography 40: 1326-1335.
Ploug H, Iversen MH, Fischer G. (2008). Ballast, sinking velocity, and apparent diffusivity within marine snow and zooplankton fecal pellets: implications for substrate turnover by attached bacteria. Limnology and Oceanography 53: 1878-1886.

Ploug H, Jørgensen BB. (1999). A net-jet flow system for mass transfer and microsensor studies of sinking aggregates. Marine Ecology Progress Series 176: 279-290.

Ploug H, Passow U. (2007). Direct measurement of diffusivity within diatom aggregates containing transparent exopolymer particles (TEP). Limnol Oceanogr 52: 1-6.

Porter KG, Feig YS. (1980). The use of DAPI for identifying and counting aquatic microflora. Limnology and Oceanography 25: 943-948.

Schreiber U. (1986). Detection of rapid induction kinetics with a new type of high-frequency modulated chlorophyll fluorometer. Photosynthesis Research 9: 261-272.

Schwinghamer P. (1991). Seperation and concentration of living dinoflagellate resting cysts from marine sediments via density-gradient centrifugation. Limnol Oceanogr 36: 588-592.

Shanks AL, Edmondson EW. (1989). Laboratory-made artificial marine snow: a biological model of the real thing. Mar Biol 101: 463-470.

Smetacek VS. (1985). Role of sinking in diatom life history cycles- ecological, evolutionary and geological significance. Marine Biology 84: 239-251.

Smith DC, Steward GF, Long RA, Azam F. (1995). Bacterial mediation of carbon fluxes during a diatom bloom in a mesocosm. Deep-Sea Research Part Ii-Topical Studies in Oceanography 42: 75-97.

Staats N, Stal LJ, Mur LR. (2000). Exopolysaccharide production by the epipelic diatom Cylindrotheca closterium: effects of nutrient conditions. Journal of Experimental Marine Biology and Ecology 249: 13-27.

Stoderegger KE, Herndl GJ. (1999). Production of exopolymer particles by marine bacterioplankton under contrasting turbulence conditions. Marine EcologyProgress Series 189: 9-16.

Tien CJ, Sigee DC, White KN. (2005). Characterization of surface sugars on algal cells with fluorescein isothiocyanate-conjugated lectins. Protoplasma 225: 225-233.

Vaulot D, Olson RJ, Chisholm SW. (1986). Light and dark control of the cell cycle in 2 marine phytoplankton species. Experimental Cell Research 167: 38-52.

Waite AM, Olson RJ, Dan HG, Passow U. (1995). Sugarcontaining compounds on the cell surfaces of marine diatoms measured using concanavalin A and flow cytometry. Journal of Phycology 31: 925-933.

Weast RC. (1968). Handbook Chemistry and Physics. 49th edn, CRC for Soil and Land Management: Boca Raton, FL, USA.

Wichels A, Wurtz S, Dopke H, Schutt C, Gerdts G. (2006). Bacterial diversity in the breadcrumb sponge Halichondria panicea (Pallas). Fems Microbiology Ecology 56: 102-118.

ZoBell CE. (1941). Studies on marine bacteria. I. The cultural requirements of heterotrophic aerobes. J Mar Res 4: 42-75. 